\title{
Peripheral blood (PB) concentrations of neutrophil chemoattractant IL-8 and Th1-related cytokines are elevated during febrile episodes in children with periodic fever, aphthous stomatitis, pharyngitis and adenitis (PFAPA) syndrome
}

\author{
Liora Hare ${ }^{3^{*}}$, Eduard Ling ${ }^{2}$, Tirza Klein ${ }^{1}$, Moshe Israeli ${ }^{1}$, Jacob Amir ${ }^{3}$
}

From 2011 Pediatric Rheumatology Symposium sponsored by the American College of Rheumatology Miami, FL, USA. 2-5 June 2011

\section{Purpose}

PFAPA is an autoinflammatory syndrome of childhood characterized by recurrent attacks of fever, aphthous stomatitis, pharyngitis and adenitis. The underlying immune disorder is poorly understood, albeit activation of Th1 related cytokines has been observed. We aimed to compare concentration of proinflammatory cytokines and selected chemokines in PB during and between febrile episodes in children with PFAPA.

\section{Methods}

Twenty three children with PFAPA (8 girls and 15 boys, age $7 \pm 1.7$ ye, range $5-9$ ye), observed at Pediatric Rheumatology Unit of Schneider Children's Medical Center of Israel, participated in the study. PB was drawn during febrile episodes and between attacks (12 and 18 blood samples, respectively). PB samples of two of febrile children were matched with blood samples of the same children between febrile attacks. Concentration of GM-CSF, INF $\gamma$, IL-1 $\beta$, IL-2, IL-4, IL-5, IL-6, IL-8, IL-10 and TNF $\alpha$ were simultaneously measured in $\mathrm{PB}$ using the multiplex ELISA technique.

\section{Results}

PB concentration of IL-8 increased 50-fold (3508.47 $+2907.16 \mathrm{pg} / \mathrm{ml}$ vs $74.36+116.73 \mathrm{pg} / \mathrm{ml}$, respectively, $\mathrm{p}<0.001)$ during febrile episodes. Concentrations of IFN $\gamma$, IL-1 $\beta$, IL-2, IL- 6 and TNF $\alpha$ were significantly

\footnotetext{
${ }^{3}$ Schneider Children's Medical Center of Israel, Petach Tikvah, Israel Full list of author information is available at the end of the article
}

increased during febrile episodes $(11.65 \pm 6.62 \mathrm{pg} / \mathrm{ml}$, $57.09 \pm 1637.91 \mathrm{pg} / \mathrm{ml}, 10 \pm 0.88 \mathrm{pg} / \mathrm{ml}, 150.79 \pm 2243.16$ $\mathrm{pg} / \mathrm{ml}$ and $45.53 \pm 119.39 \mathrm{pg} / \mathrm{ml}$ vs. $7 \pm 12.69 \mathrm{pg} / \mathrm{ml}, 9 \pm 16 /$ $8 \mathrm{pg} / \mathrm{ml}, 10 \pm 0.4 \overline{5} \mathrm{pg} / \mathrm{ml}, 9.47 \pm 42.3 \overline{4} \mathrm{pg} / \mathrm{ml}$ and $16+8.7$ $\mathrm{pg} / \mathrm{ml}$, respectively, $\mathrm{p}<0.001)$. Concentration of $\overline{\mathrm{L}} 10$ decreased during febrile episodes $(6 \pm 1.19 \mathrm{pg} / \mathrm{ml}$ vs. 6 $\pm 2.22, \mathrm{p}<0.003)$, whereas expression of GM-CSF, IL-4, $\overline{\mathrm{IL}}-5$ remained unchanged.

\section{Conclusion}

PFAPA febrile episodes are characterized by activation of chemokine IL-8, indicating the potential involvement of neutrophils in pathogenesis of the syndrome. Elevation of concentration of proinflammatory cytokines IFN $\gamma$, TNF $\alpha$, IL1 $\beta$ and IL- 6 coupled with lack of activation of IL- 4 and IL-5 indicate innate immune response with Th1 skewing without involvement of Th2. Expression of eosinophil growth factor IL-5 did not change, indicating the lack of eosinophils' role in pathogenesis of PFAPA. Decreased expression of suppressor cytokine IL-10 during febrile episode indicates disordered immune regulation.

\section{Disclosure}

Liora Harel: None; Eduard Ling: None; Tirza Klein: None; Moshe Israeli: None; Jacob Amir: None.

\footnotetext{
Author details

${ }^{1}$ Rabin Medical Center, Petach Tikvah, Israel. ${ }^{2}$ Rabin Medical Center, Campus Beilinson, Petach Tikvah, Israel. ${ }^{3}$ Schneider Children's Medical Center of Israel, Petach Tikvah, Israel.
} 
Cite this article as: Harel et al: Peripheral blood (PB) concentrations of neutrophil chemoattractant IL-8 and Th1-related cytokines are elevated during febrile episodes in children with periodic fever, aphthous stomatitis, pharyngitis and adenitis (PFAPA) syndrome. Pediatric

Rheumatology 2012 10(Suppl 1):A113.

Submit your next manuscript to BioMed Central and take full advantage of:

- Convenient online submission

- Thorough peer review

- No space constraints or color figure charges

- Immediate publication on acceptance

- Inclusion in PubMed, CAS, Scopus and Google Scholar

- Research which is freely available for redistribution

Submit your manuscript at www.biomedcentral.com/submit
C Biomed Central 